\title{
The Participation of Wall Monolignols in Leaf Tolerance to Nature Flooding of Hydrophytes
}

\author{
Olena M. Nedukha \\ Department of Cell Biology and Anatomy, Institute of Botany, National Academy of Sciences of Ukraine, Kiev, \\ Ukraine \\ Email: o.nedukha@hotmail.com
}

Received 28 April 2015; accepted 17 August 2015; published 20 August 2015

Copyright (C) 2015 by author and Scientific Research Publishing Inc.

This work is licensed under the Creative Commons Attribution International License (CC BY).

http://creativecommons.org/licenses/by/4.0/

(c) (i) Open Access

\begin{abstract}
The comparative analysis of the monolignols localization in epidermis, photosynthesizing parenchyma and vessels walls of Myriophyllum spicatum, Potamogeton pectinatus and $P$. perfoliatus submerged leaves carried out on the basis of cytochemical method and laser confocal microscopy. The images of quantitative distribution of syringyl and guaiacyl in the cell walls were obtained at cellular level depending on the type of leaf tissues and plant species. The increase of relative content of monolignols was established in walls of vessels and in the corners of parenchyma cells. Cytochemical analysis indicates that ratio of syringyl/guaiacyl in leaf tissues changes depending on species. The role of of syringyl and guaiacyl monolignols in the cellular mechanisms of adaptation to nature flooding is discussed.
\end{abstract}

\section{Keywords}

Flooding, Monolignols, Hydrophytes, Leaves, Laser Scanning Microscopy

\section{Introduction}

Soil water logging and flooding are the one of the major abiotic stresses for plants. The appearance of serious problem in agriculture as well as in plant natural populations is provoked by the stresses. The stress effects plant growth, because during flood occurs the shortage of oxygen and $\mathrm{CO}_{2}$ due to the change diffusion rates of gasses in water [1]-[3]. The outer cell walls of submerged leaves and shoots are the one and the main barriers between plant and water environment. Epidermis and mesophyll of submerged stem and leaves of hydrophytes adapt to water environment by change of wall structure and absent of stomata and wax. The recent data showed the presence of cuticle pores in the outer cell walls of the submerged leaves of some hydrophytes and rice seedlings 
[4] [5]. Besides, the effect of submergence on lignin and cellulose content in the submerged shoots of Ludwigia repens [6], Trapa natans and Sagittaria sagittifolia [7] was established.

Lignin is the biopolymer of aromatic alcohols, that is synthesized in secondary cellular walls that made off growth by enlargement, and participates in adaptation of plant to the stress, changing structure of cellular wall matrix, providing impassability of water and water solutions through xylem vessel walls of leading bunches and forming in an epidermis a barrier to the pathogens. A lignin is characterized by hydrophobic, this polymer substitute for a water in a wall, forming to hydrogen and covalently association between polysaccharides and hemicelluloses [8]. Content of lignin in the walls is big (from 27\% to 81.7\%), and depends on plant age and cell differentiation [9]. Lignification of walls strengthens the protective function of cells at infecting, reduces speed of growth cell, strengthens mechanical durability of cells, and also reduces permeability to water through apoplast [10].

Lignin is highly branched and composed of cross-linked units, monolignols that derive from three hydroxycinnamyl alcohol monomers differing in their degree of methoxylation, $p$-coumaryl, coniferyl, and sinapyl alcohols [11] [12]. These monolignols produce, respectively, $p$-hydroxyphenyl (H), guaiacyl (G), and syringyl (S) phenylpropanoid units when incorporated into the lignin polymer. It is known that a syringyl monolignol mainly enters in the composition of lignin of floral plants and spore plants, while guaiacyl, syringyl and p-hydroxyphenyl monolignols enter in the composition of lignin of many vascular plants [13].

Real hydrophytes and marsh plants grow in condition of soil flooding or complete submergence. These plants adapt to reduction of free oxygen in soil and to constant water environment. Such plants are generated the specified adaptative mechanisms at different levels: tissular, cellular and subcellular [14]-[16]. Submerged leaves become thinner, structure and type photosynthesizing and epidermal cells change; stomata and wax no form, ultrastructure cells and cellulose content of epidermal tissue change significantly [5]. So much the lignin and monolignols of cell walls of hydrophytes species that adapt to complete submergence are not studied enough. Therefore, in this research we used submerged leaves of three species of hydrophytes (Myriophyllum spicatum L., Potamogeton pectinatus L. and P. perfoliatus L.). Selected aquatic plant species are typical for the Ukrainian flora. $M$. spicatum L., $P$. pectinatus and $P$. perfoliatus are known to be aquatic plants with submerged leaves, which grow and reproduce (from June to September, in Ukraine). These plants grow at the riverside, in water, at differential depth (from soil flooding to water surface), which successfully grow and reproduce in the Dnipro River in Ukraine. This paper presents a current picture of localization, distribution and relative content of monolignols in the leaf cell walls of some hydrophytes.

\section{Material and Methods}

\subsection{Plant Material}

Research objects were leaves of three hydrophytes: Myriophyllum spicatum (Haloraceae), Potamogeton pectinatus (Potamogetonaceae) and P. perfoliatus (Potamogetonaceae), which were identificated according to Manual on High Plants of Ukraine [17]. The leaves of plants were collected at the beginning of June at the stage of vegetative growth. We used upper leaves that finished growth by enlargement. Plants were grown in water along-shore of the Rusanivskiy canal (left Shore of Dnipro River, in Kyiv) on the depth of $80-100 \mathrm{~cm}$. The sun illumination [photosynthetic photon fluency rate (PPFR)] on water surface was 1200 - $1250 \mu$ mol quantum $\cdot \mathrm{m}^{-2} \cdot \mathrm{sec}^{-1}$, and on surface of the upper leaves of studied plants (about 8 - 10 cetimetres below the water surface) was 12 - $15 \mu \mathrm{mol}$ quantum $\cdot \mathrm{m}^{-2} \cdot \mathrm{sec}^{-1}$. PPFR was measure by the means of Light Meter Li-250 (USA, LI-COR). The leaves situated above $8-10 \mathrm{~cm}$ under water surface were used for cytochemical analysis. The temperature of water was $+15^{\circ} \mathrm{C}$ and the temperature of air was $+23^{\circ} \mathrm{C}$. The leaves of three plants from each species: submerged dissected leaves of $M$. spicatum (Figure 1(a)); submerged entire leaves of $P$. perfoliatus (Figure 1(b)), and submerged dissected leaves of $P$. pectinatus (Figure 1(c)) have been used for the cytological investigations.

The information concerning the physic-chemical property of water in Dnipro river is given by the Management of Dniepr-water resources (2015, http://www.dbuwr.com.ua/sendmail.php) and the data of ecologists [18]. Water of Dnipro River is the second class. Salts composition of water in Dnipro River (near Kiev) are carried out over last several years shown that water is clean and alkalescent, characterized by the middle salts value, notable: mineralization (sum of ions) average from 250 to $500 \mathrm{mg} / \mathrm{dm}^{3}$; chlorides - $16-24 \mathrm{mg} / \mathrm{dm}^{3}$; sulphates$13-53 \mathrm{mg} / \mathrm{dm}^{3}$; ammonium ions-0.29 - $1.08 \mathrm{mg} / \mathrm{dm}^{3}$; and dissolved oxygen-8.7 - $13.5 \mathrm{mg} / \mathrm{dm}^{3}$ (Management of Dniepr-water resources, 2015, http://www.dbuwr.com.ua/sendmail.php; [18]). 


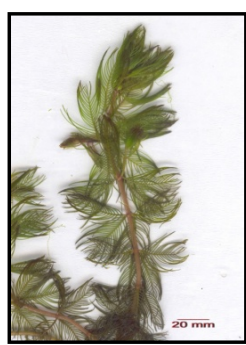

(a)

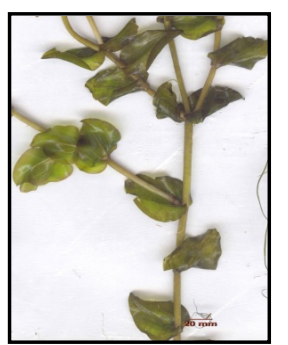

(b)

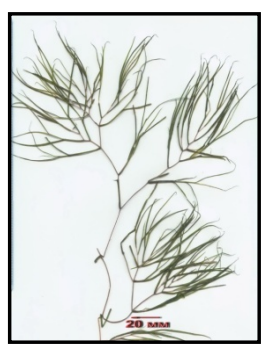

(c)

Figure 1. General view of Myriophyllum spicatum (a); Potamogeton perfoliatus (b) and P. pectinatus (c) leaves.

\subsection{Microscopy Analysis}

The cytochemical method accordingly to [19] was used for the study of both distribution monolignols (syringyl and guaiacyl) and relative content of these monolignols in walls. Leaf sections were hand cut from fresh leaf samples. For the detection of phenylpropanoids, sections were stained within 2 min with saturated $(0.25 \%$, w/v) diphenylboric acid-2-aminoethyl ester (DPBA) (Sigma) in MilliQ water containing 0.02\% (v/v) Triton-X-100, then samples intensive washed with $\mathrm{H}_{2} \mathrm{O}$. The sections were visualized immediately with an laser scanning microscope LSM 5 Pascal (Carl Zeiss, Germany). For detection of complex DPBA-syringyl fluorescence a laser was excited at $340-380 \mathrm{~nm}$, and the fluorescence emission detected at $430 \mathrm{~nm}$ wave length; and for detection of complex DPBA-guaiacyl fluorescence a laser was excited at $450-490 \mathrm{~nm}$, and the fluorescence emission detected at $520 \mathrm{~nm}$ wave length, using an $\times 10, \times 20$ and $\times 40$ objectives the PASCAL program. Chlorophyll auto fluorescence was excited at $440 \mathrm{~nm}$ and fluorescent emission detected at $660 \mathrm{~nm}$. Fluorescence intensity of monolignols was measured in the cell walls as a function of emissions wave length using the PASCAL program.

For statistical treatment took for two/three leaves from each plant, in every leaf took at least 30 different cells (epidermis, photosynthesizing parenchyma, and xylem vessels). Values of cytochemical results were expressed as the mean and standard errors. Three replications of cytological results were expressed as the mean and standard arrows. Statistical significance of relative content of monolignols in cell wall was determined using the BIO software (Institute of Botany, Kiev, Ukraine) and a Student's test $(p<0.05)$.

\section{Results and Discussion}

Submerged leaves of Myriophyllum spicatum, Potamogeton pectinatus and P. perfoliatus had various form and size (Figure 1). Leaves of Myriophyllum spicatum were feather-like, dissected (Figure 1(a)), average size of leaf dissected particle of upper leaf was $18 \pm 1.7$-at long axis and $1.25 \pm 0.5 \mathrm{~mm}$-at short axis. Clasping leaves of Potamogeton perfoliatus had solid leaflet (Figure 1(b)), size of that was $51 \pm 5.3 \mathrm{~mm}$ at long axis and $23 \pm 2.7$ $\mathrm{mm}$ - at short axis (in the middle of leaf). Leaves of $P$. pectinatus were needle-like, linear, highly dissected (Figure 1(c)), average size of leaf dissected particle was $57 \pm 5.9 \mathrm{~mm}$ at long axis and $1.3 \pm 0.5 \mathrm{~mm}$ —at short axis.

\subsection{Myriophyllum spicatum}

Cytochemical analysis of monolignols in the dissected leaves of M. spicatum are shown as blue fluorescence for syringyl and as green fluorescence for guaiacyl in the walls of epidermis, photosynthesizing parenchyma and also in xylem vessels (Figures 2(a)-(d)). But the fluorescence intensity of DPKK-syringyl and DPKK-guaiacyl complex was different in the tissues (Table 1; Figure 2(e) and Figure 2(f)). Wall of vessels and anticlinal wall of epidermis had the greatest fluorescence intensity of DPKK-syringyl and DPKK-guaiacyl complex in comparison with other walls of epidermis and parenchyma $\left(1^{\text {st }}-4^{\text {th }}\right.$ layers). It should be noted that in the corners of parenchyma cells fluorescence of monolignols was considerably higher, than along walls. Except it, attitude of content of syringyl toward guaiacyl in the walls of photosynthesizing parenchyma was high enough, especially in the first layers to the parenchyma. The size of $S / G$ ratio in cells takes place in the next order: anticlinal walls of epidermis $>$ walls in the corners of parenchyma $>$ vessel walls $>$ parenchyma walls $>$ periclinal walls of epidermis. It is revealed that maximum frequency for syringyl in the epidermal cell was 225787 (pixels, blue graph), the maximum frequency for guaiacyl was 286463 (pixels, green graph), and the maximum frequency for auto fluorescence of chlorophyll was 358132 (pixels, red graph) (Figure 2(g)). 


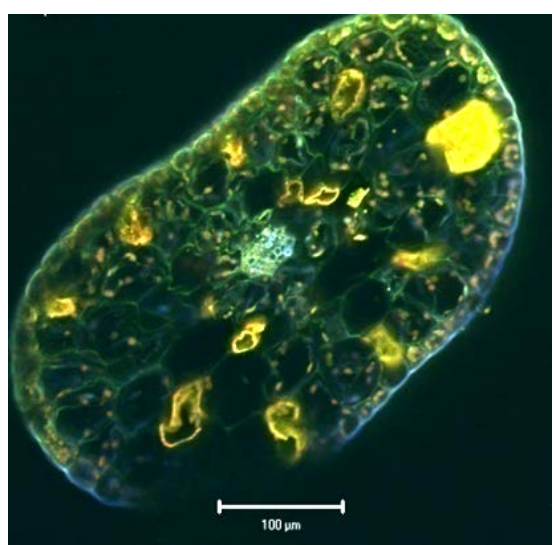

(a)

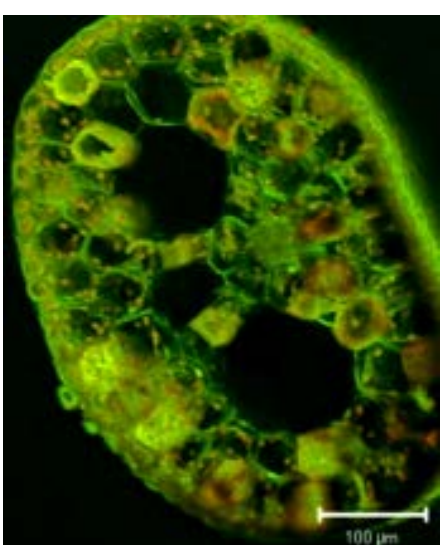

(b)

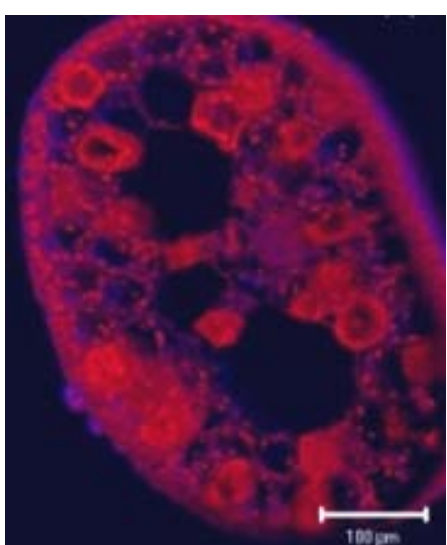

(c)

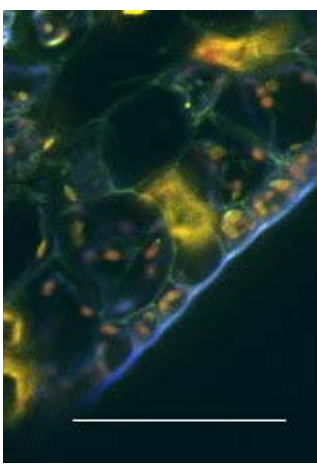

(d)

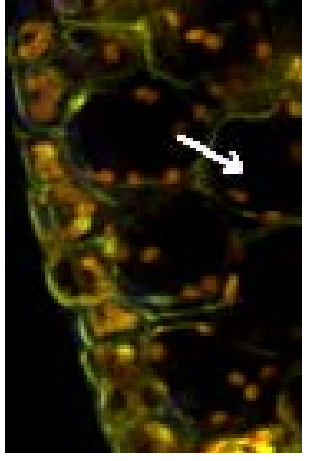

(e)

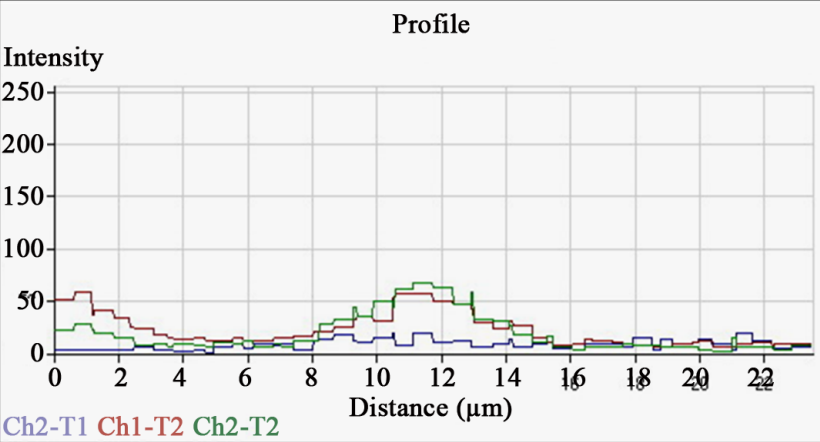

(f)

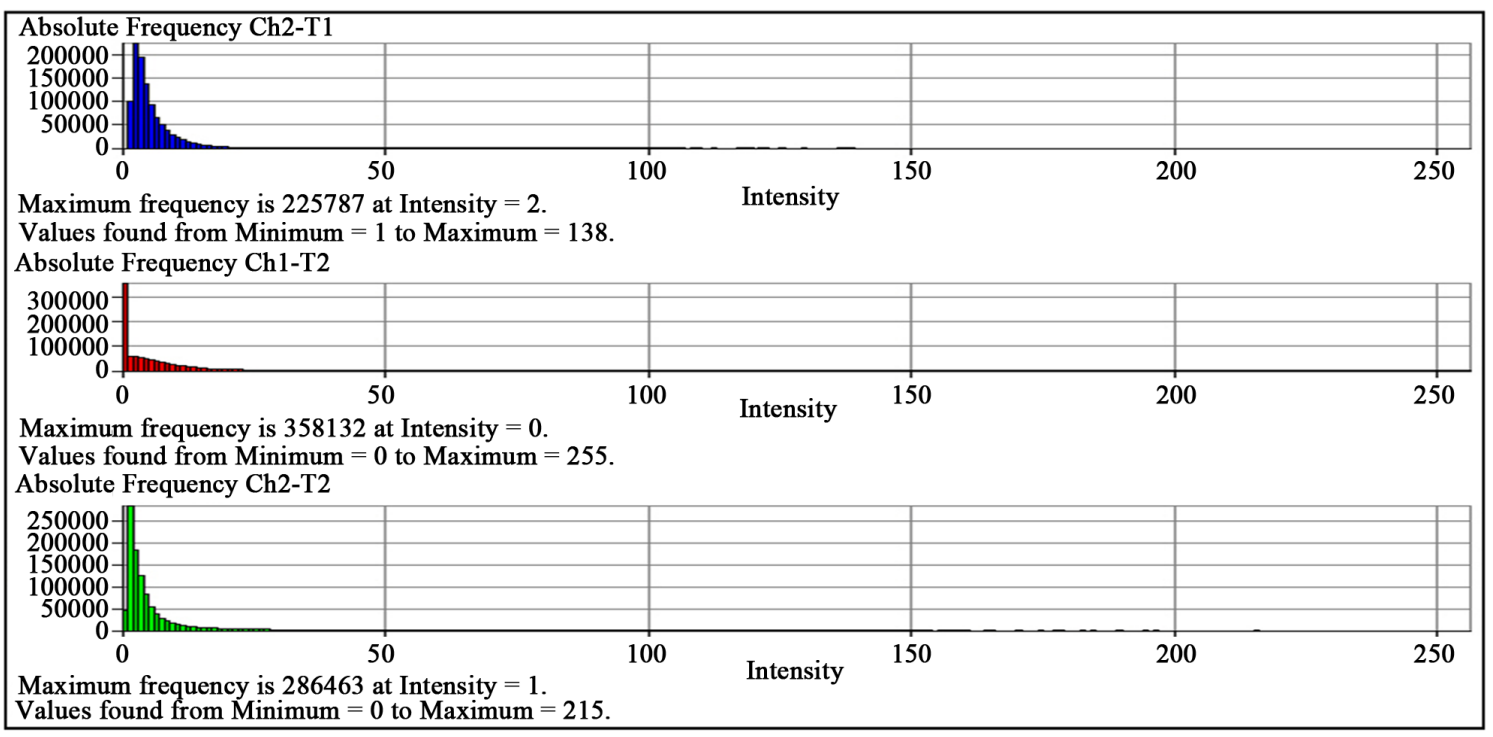

(g)

Figure 2. Micrographs of cytochemical fluorescence of monolignols in the leaf cells of Myriophyllum spicatum. Localization of syringyl has blue fluorescence and guaiacyl-green fluorescence; chlorophyll—red auto fluorescence. Monolignols are shown: on figures (a), (d) syringyl + guaiacyl in walls; on (b) guaiacyl, on (c) syringyl. On the (e), (f) histogram of fluorescence intensity of syrigyl (blue line), guaiacyl (green line) and chlorophyll auto fluorescence intensity (red line). Ordinate-Fluorescence intensity, relative units (pixels). Abscissa-distance ( $\mu \mathrm{m})$, which was scanned on the (e). This distance is shown as white line on the (e). On the (g) is shown absolute frequency of pixels for syringyl (blue graph), for guaiacyl (green graph) and for auto fluorescence of chlorophyll (red graph). Bars $=100 \mu \mathrm{m}$. 
Table 1. The intensity of complex DPBA-syringyl and DPBA-guaiacyl fluorescence in leaves of Myriophyllum spicatum. (data are means \pm SD of 3 replicates. 30 - 35 cells of epidermis, 50 - 60 cells of parenchyma and 15 - 17 cells of vessels used in each replicate).

\begin{tabular}{|c|c|c|c|c|}
\hline \multirow{2}{*}{ Tissue/cell wall } & \multicolumn{3}{|c|}{ Intensity of monolignols fluorescence, relative units } & \multirow{2}{*}{$\mathrm{S} / \mathrm{G}$} \\
\hline & Syringyl & Guaiacyl & $\mathrm{S}+\mathrm{G}$ & \\
\hline \multicolumn{5}{|l|}{ Epidermis: } \\
\hline Outer periclinal wall & $19 \pm 0.7$ & $48 \pm 2.7^{*}$ & $67 \pm 1.7$ & 0.396 \\
\hline Inner periclinal wall & $62 \pm 5.3$ & $49 \pm 3.7$ & $111 \pm 5$ & 1.26 \\
\hline Anticlinal wall & $140 \pm 17$ & $80 \pm 7.9^{*}$ & $220 \pm 13$ & 1.75 \\
\hline \multicolumn{5}{|l|}{ Photosynthesizing parenchyma: } \\
\hline $1^{\text {st }}$ layer & $65 \pm 5.7$ & $50 \pm 3.9$ & $115 \pm 5$ & 1.3 \\
\hline $2^{\text {nd }}-4^{\text {th }}$ layers & $30 \pm 1.5$ & $46 \pm 2.7^{*}$ & $76 \pm 2.1$ & 0.65 \\
\hline Walls in corners of cell junction & $120 \pm 11$ & $70 \pm 6.9^{*}$ & $190 \pm 9$ & 1.7 \\
\hline Vessels & $175 \pm 18$ & $125 \pm 19^{*}$ & $300 \pm 18$ & 1.4 \\
\hline
\end{tabular}

*Values of guaiacyl is significantly different $(p \leq 0.05)$ from syringyl.

\subsection{Potamogeton perfoliatus}

Like fluorescence of monolignols observed in $P$. perfoliatus leaves. Cytochemical analysis of the complex DPKK-syringyl and DPKK-guaiacyl in leaves shown blue fluorescence of syringyl and green fluorescence of guaiacyl in cell walls of epidermis, photosynthesizing parenchyma and vessels cells (Figures 3(a)-(c)). There were some differences in fluorescence intensity of monolignols in cell walls of epidermis, in the corner of parenchyma cells and cell of vessels. The level of fluorescence intensity of monolignols is presented in the Table 2 and Figure 3(d) and Figure 3(e) (diagram). It is necessary to note that syringyl was not exposed in cellular walls of $2^{\text {nd }}, 3^{\text {rd }}$ and $4^{\text {th }}$ layers of parenchyma (of three plants) and in plans four-intensity of fluorescent was $7 \pm 0.6$ relative units; notably, minute intensity. On the size of the relation of $\mathrm{S} / \mathrm{G}$ cells in $P$. perfoliatus are situated in such order: walls in the corners of parenchyma $>$ vessels $>$ periclinal walls of epidermis $>$ anticlinal walls of epidermis > parenchyma. Luminescence intensity of monolignols in $P$. perfoliatus leaves differ from $M$. spicatum leaves: 2.1 - 3.2 times guaiacyl increased in epidermis walls and 5 times-in walls of $1^{\text {st }}$ layer of parenchyma. It is necessary to note that independently from leaf species the relative content of monolignols in vessel walls was more than other tissue walls. It is revealed that maximum frequency for syringyl in the epidermal cell was 314166 (pixels, blue graph), the maximum frequency for guaiacyl was 209942 (pixels, green graph), and the maximum frequency for auto fluorescence of chlorophyll was 400695 (pixels, red graph) (Figure 3(f)).

\subsection{Potamogeton pectinatus}

Cytochemical analysis of monolignols in leaves of $P$. pectinatus is showed blue fluorescence of syringyl and green fluorescence of guaiacyl in the cell wall of epidermis, parenchyma and vessels cells, similar to that in leaves of $M$. spicatum leaves and $P$. perfoliatus (Figures 4(a)-(c)). The level of luminescence intensity is presented in Table 3 and Figure 4(d) and Figure 4(e) (diagram). The analysis of monolignols luminescence intensity showed that relative content of guaiacyl in walls of periclinal walls of epidermis, in corners of parenchyma cells and in vessels was more than that in cell walls of anticlinal walls of epidermis and parenchyma cell walls. The size of S/G was lowest in the corners of parenchyma cells. The size of S/G ratio in cells takes place in the next order: parenchyma > epidermis > vessels $>$ walls in the corners of parenchyma. It is revealed that maximum frequency for syringyl in the epidermal cell was 104477 (pixels, blue graph), the maximum frequency for guaiacyl was 24534 (pixels, green graph), and the maximum frequency for auto fluorescence of chlorophyll was 61963 (pixels, red graph) (Figure 4(f)).

Thus, we showed the presence of syringyl and guaiacyl monolignols in submerged leaves of three species real hydrophytes (Myriophyllum spicatum, Potamogeton pectinatus and P. perfoliatus) and also the increased content 
Table 2. The intensity of complex DPBA-syringyl and DPBA-guaiacyl fluorescence in leaves of Potamogeton perfoliatus. (data are means \pm SD of 3 replicates. 30 - 35 cells of epidermis, 50 - 60 cells of parenchyma and 15 - 17 cells of vessels used in each replicate).

\begin{tabular}{|c|c|c|c|c|}
\hline \multirow{2}{*}{ Tissue/cell wall } & \multicolumn{3}{|c|}{ Intensity of monolignols fluorescence, relative units } & \multirow{2}{*}{$\mathrm{S} / \mathrm{G}$} \\
\hline & Syringyl & Guaiacyl & $\mathrm{S}+\mathrm{G}$ & \\
\hline \multicolumn{5}{|l|}{ Epidermis adaxial: } \\
\hline Outer periclinal wall & $32 \pm 2.9$ & $103 \pm 13^{*}$ & $135 \pm 8$ & 0.31 \\
\hline Inner periclinal wall & $31 \pm 3.0$ & $200 \pm 17^{*}$ & $231 \pm 12$ & 0.15 \\
\hline Anticlinal wall & $30 \pm 3.7$ & $176 \pm 19^{*}$ & $206 \pm 12$ & 0.17 \\
\hline \multicolumn{5}{|l|}{ Epidermis abaxial: } \\
\hline Outer periclinal wall & $47 \pm 3.9$ & $120 \pm 13^{*}$ & $167 \pm 8$ & 0.39 \\
\hline Inner periclinal wall & $45 \pm 3.3$ & $205 \pm 19^{*}$ & $250 \pm 12$ & 0.22 \\
\hline Anticlinal wall & $37 \pm 4.5$ & $255 \pm 19^{*}$ & $292 \pm 12$ & 0.14 \\
\hline \multicolumn{5}{|l|}{ Photosynthesizing parenchyma: } \\
\hline $1^{\text {st }}$ layer & $30 \pm 3.3$ & $250 \pm 13^{*}$ & $280 \pm 9$ & 0.12 \\
\hline $2^{\text {nd }}-4^{\text {th }}$ layers & No expose ${ }^{* *}$ & $25 \pm 3.1$ & $25 \pm 3.1$ & - \\
\hline Walls in corners of cell junction & $147 \pm 13$ & $59 \pm 7.2^{*}$ & $206 \pm 10$ & 2.49 \\
\hline Vessels & $215 \pm 22$ & $255 \pm 21$ & $470 \pm 21$ & 0.84 \\
\hline
\end{tabular}

*Values of guaiacyl is significantly different $(p \leq 0.05)$ from syringyl; ${ }^{* *}$ In leaf cells of three plants syringyl was not exposed, and in plans four-intensity of fluorescent was $7 \pm 0.6$ relative units; notably, minute intensity.

Table 3. The intensity of complex DPBA-syringyl and DPBA-guaiacyl fluorescence in leaves of Potamogeton pectinatus (data are means \pm SD of 3 replicates. 30 - 35 cells of epidermis, 50 - 60 cells of parenchyma and 15 - 17 cells of vessels used in each replicate).

\begin{tabular}{|c|c|c|c|c|}
\hline \multirow{2}{*}{ Tissue/cell wall } & \multicolumn{3}{|c|}{ Intensity of monolignols fluorescence, relative units } & \multirow{2}{*}{$\mathrm{S} / \mathrm{G}$} \\
\hline & Syringyl & Guaiacyl & $\mathrm{S}+\mathrm{G}$ & \\
\hline \multicolumn{5}{|l|}{ Epidermis: } \\
\hline Outer periclinal wall & $61 \pm 8.3$ & $126 \pm 12^{*}$ & $187 \pm 11$ & 0.48 \\
\hline Inner periclinal wall & $22 \pm 2.9$ & $25 \pm 3.1$ & $47 \pm 3.1$ & 0.88 \\
\hline Anticlinal wall & $15 \pm 2.8$ & $23 \pm 3.5$ & $38 \pm 3.2$ & 0.65 \\
\hline \multicolumn{5}{|l|}{ Photosynthesizing parenchyma: } \\
\hline $1^{\text {st }}$ layer cells & $20 \pm 3.9$ & $23 \pm 3.5$ & $43 \pm 3.7$ & 0.87 \\
\hline $2^{\text {nd }}-4^{\text {th }}$ layers cells & $27 \pm 3.1$ & $52 \pm 7.3^{*}$ & $59 \pm 5.2$ & 0.52 \\
\hline Walls in corners of cell junction & $40 \pm 3.9$ & $220 \pm 21^{*}$ & $260 \pm 13$ & 0.18 \\
\hline Vessels & $88 \pm 7.1$ & $170 \pm 13^{*}$ & $258 \pm 11$ & 0.52 \\
\hline
\end{tabular}

\footnotetext{
*Values of guaiacyl is significantly different $(p \leq 0.05)$ from syringyl.
} 


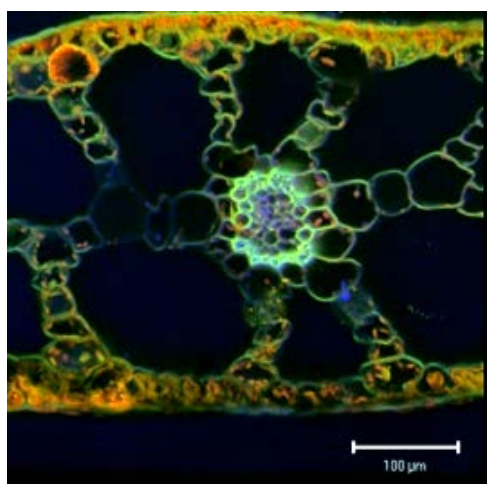

(a)

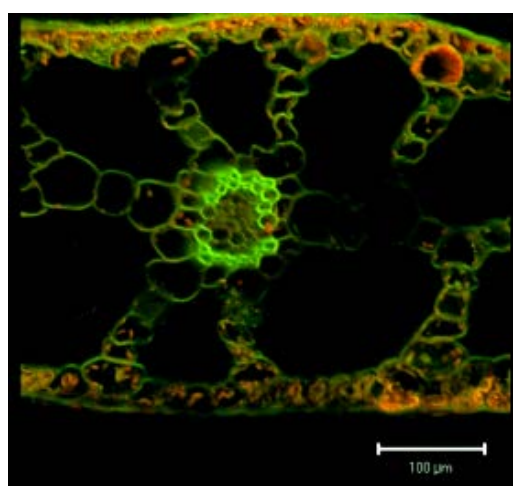

(b)

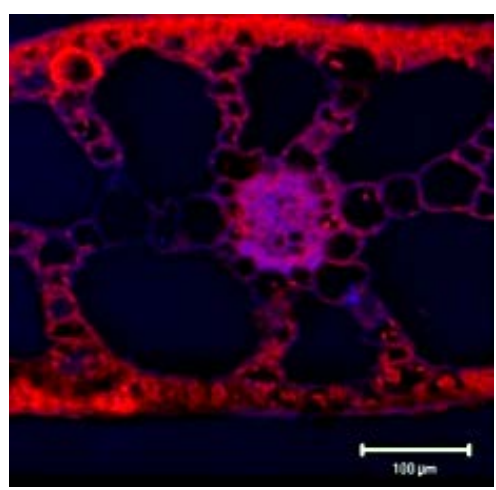

(c)

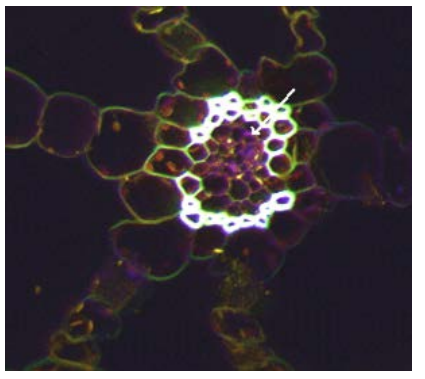

(d)

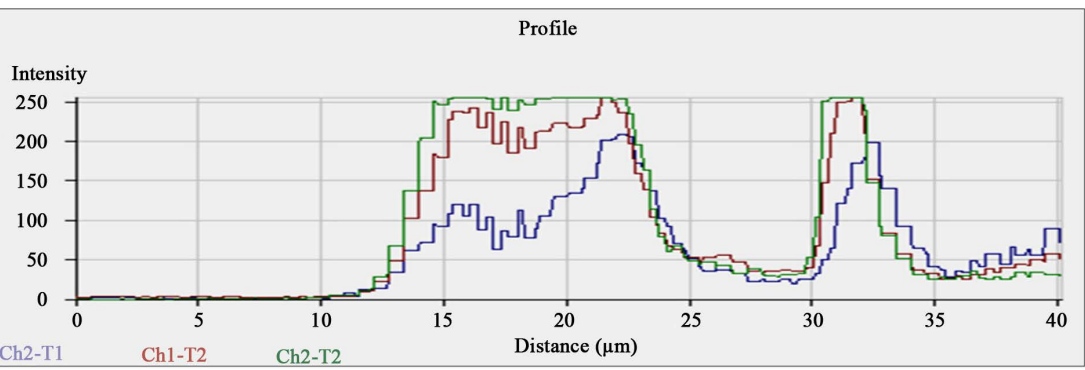

(e)

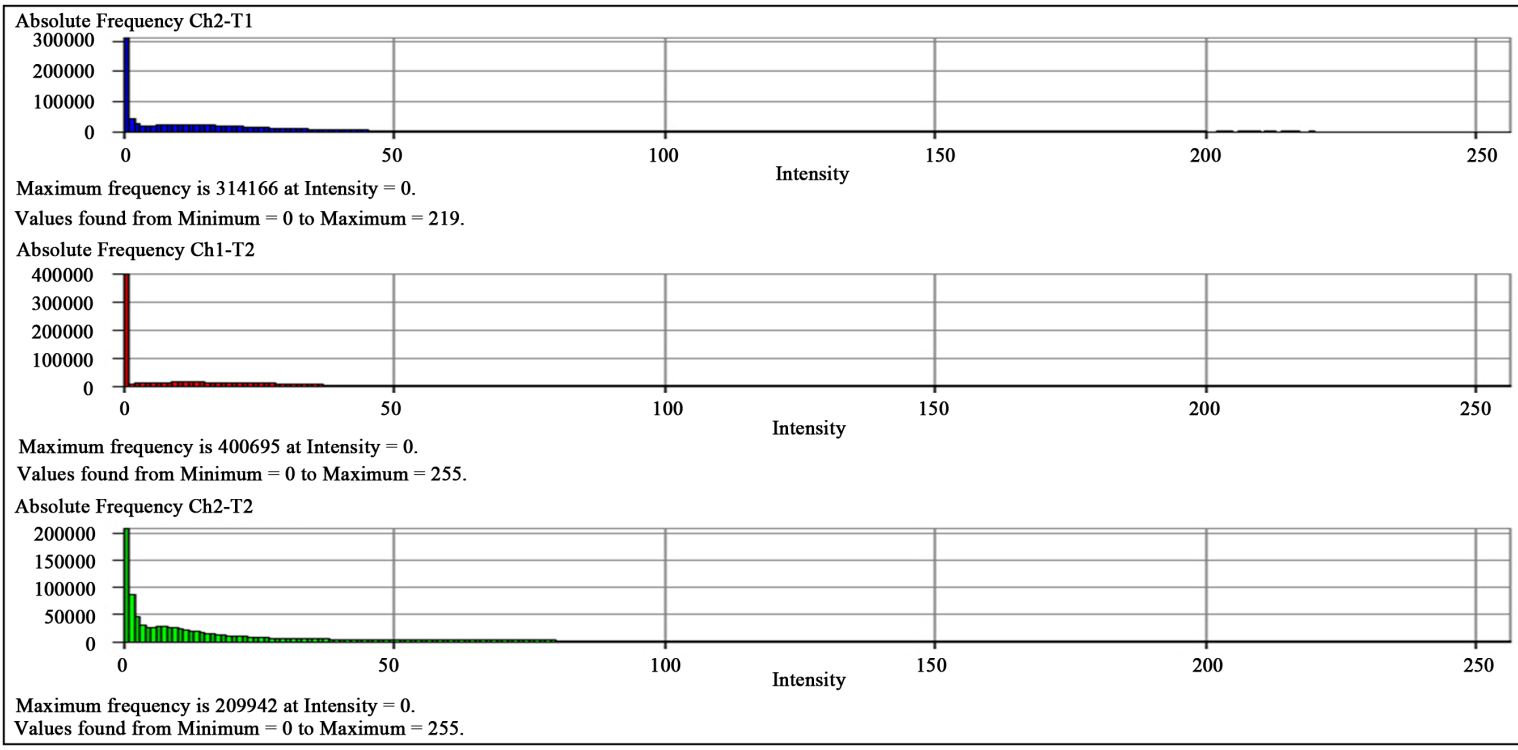

(f)

Figure 3. Micrographs of cytochemical fluorescence of monolignols in the leaf cells of Potamogeton perfoliatus. Localization of syringyl has blue fluorescence and guaiacy-green fluorescence; and chlorophyll-red auto fluorescence. Monolignols are shown: on (a), (d) syringyl + guaiacyl in walls; on (b) guaiacyl: on (c) syringyl. On (d), (e) histograms of fluorescence intensity of syrigyl (blue line), guaiacyl (green line) and chlorophyll auto fluorescence intensity (red line). Ordinate-Fluorescence intensity, relative units (pixels). Abscissa-Distance $(\mu \mathrm{m})$, which was scanned on the (d). This distance is shown as white line on the (e); On (f) is shown absolute frequency of pixels for syringyl (blue graph), for guaiacyl (green graph) and for auto fluorescence of chlorophyll (red graph). Bars $=100 \mu \mathrm{m}$.

of guaiacyl in walls only of two species of Potamogeton. There were the general and differentia signs concerning these monolignols in hydrophytes leaves. General signs were: 1) presence of syringyl and guaiacyl at the investigated species regardless of conditions of growth of leaves; 2) almost identical (sufficiently great) content of S/G 


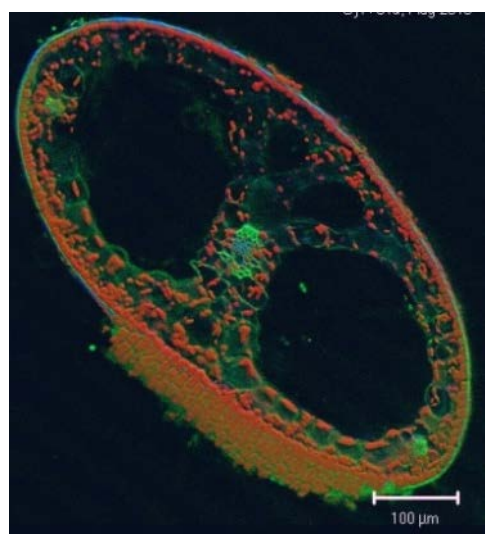

(a)

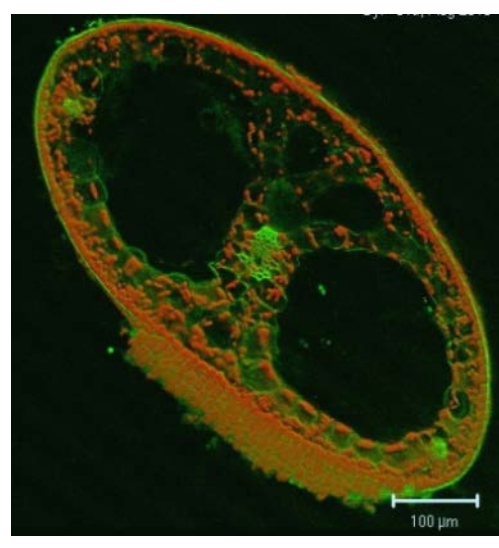

(b)

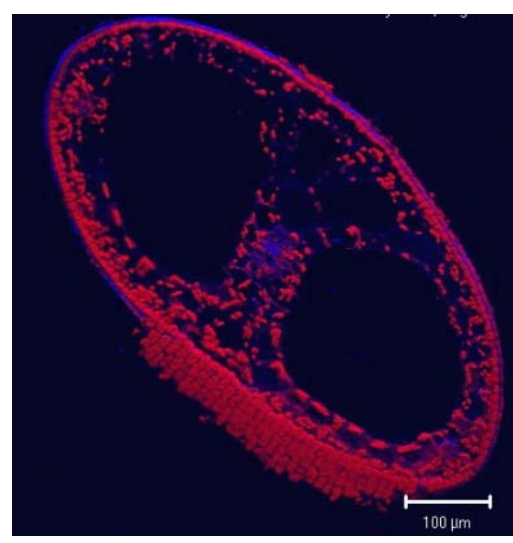

(c)

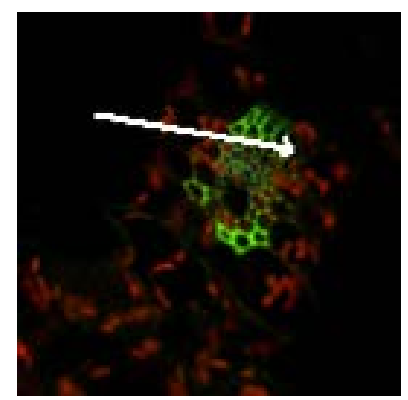

(d)

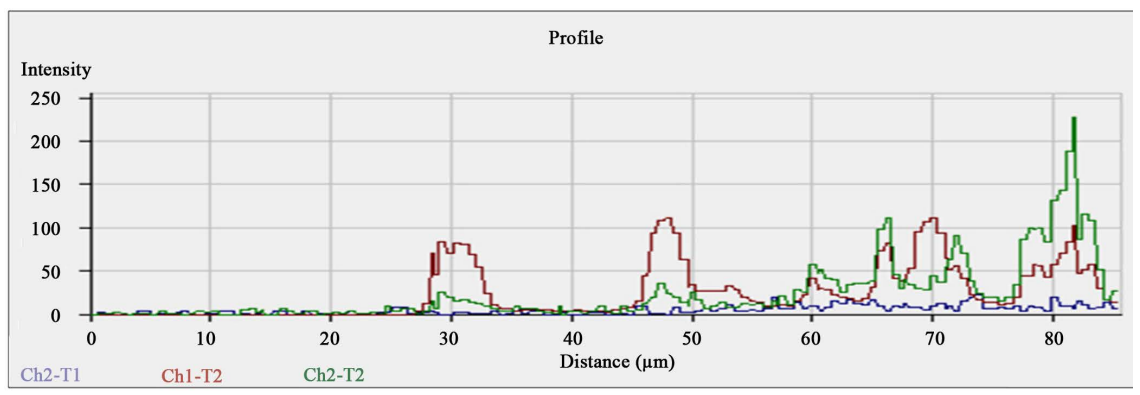

(e)

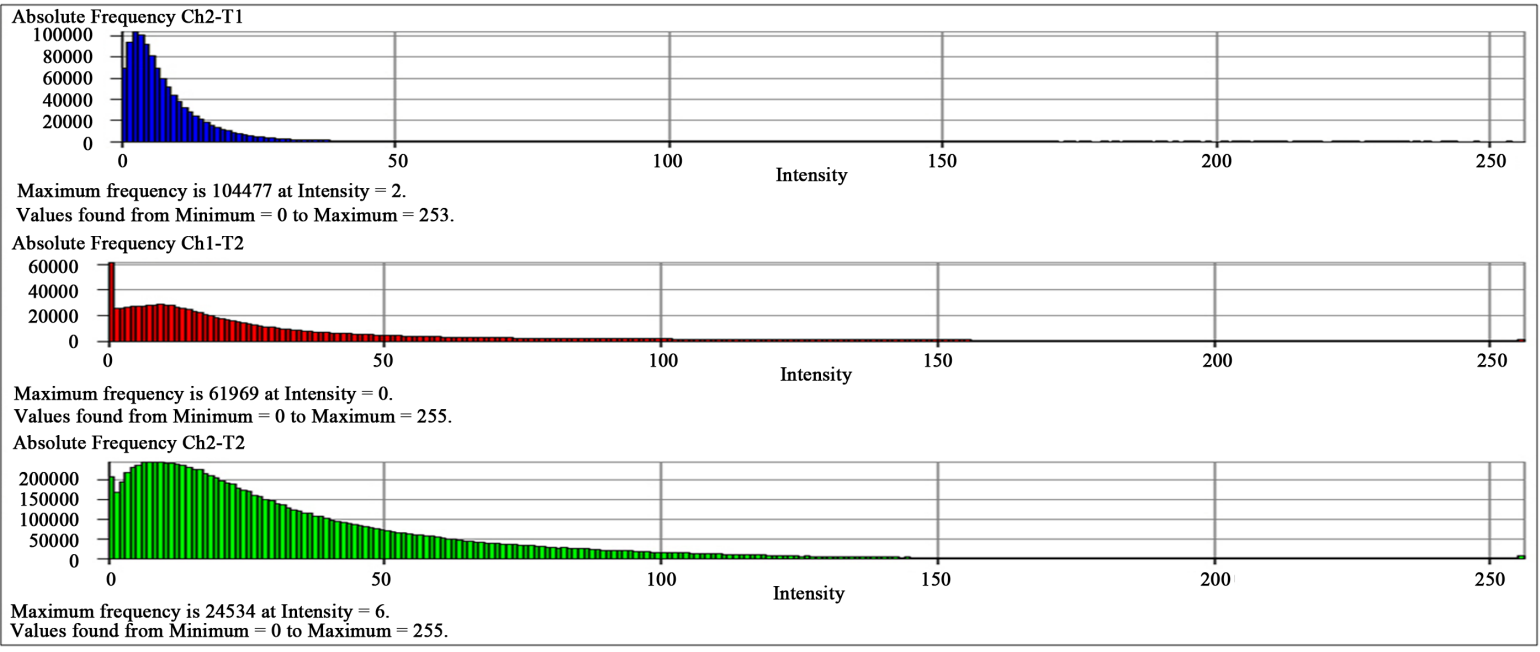

(f)

Figure 4. Micrographs of cytochemical fluorescence of monolignols in the leaf cells of Potamogeton pectinatus. Localization of syringyl has blue fluorescence and guaiacyl—green fluorescence; and chlorophyll—red auto fluorescence. Monolignols are shown: on (a) syringyl + guaiacyl in walls; on (b) guaiacyl; on (c) syringyl. On (d), (e) histogram of fluorescence intensity of syrigyl (blue line), guaiacyl (green line) and chlorophyll auto fluorescence intensity (red line). Ordinate-Fluorescence intensity, relative units (pixels). Abscissa-Distance $(\mu \mathrm{m})$, which was scanned on the (d). This distance is shown as white line on the (d). On (f) is shown absolute frequency of pixels for syringyl (blue graph), for guaiacyl (green graph) and for auto fluorescence of chlorophyll (red graph). Bars $=100 \mu \mathrm{m}$.

in the vessels cells of all hydrophytes, and in the corners of parenchyma cells of $M$. spicatum and P. perfoliatus; and 3) certain polarity of S/G ratio, that characteristic for every species. Differentia cytochemical signs were: relative content of syringyl and guaiacyl in different tissues of hydrophytes, and also different quantity of S/G in epidermis, parenchyma and vessels walls of all studied hydrophytes. 
In consideration of presence of magnified content of syringyl and guaiacyl in the corners of parenchyma cells of the investigated samples of hydrophytes and the well-known data that the middle lamella and the cell corners are the so-called nucleation sites of lignin and also they rich in $\mathrm{Ca}^{2+}$ pectate [8] [20] and are the first sites to be lignified, we can to draw a conclusion that cell corners of parenchyma cells of hydrophytes is also leading spots for lignin synthesis.

The cytochemical analysis of monolignols in different tissues of submerged leaves of M. Spicatum, P. pectinatus and $P$. perfoliatus) revealed the increase content of syringyl and guaiacyl in epidermis cell walls in comparison with walls of inner layers of photosynthesizing parenchyma. It is known that submerged leaves of hydrophytes are losing trichomes, stomata and thicker cuticle [5]; therefore the surface of epidermal cells in submerged leaves become more accessible for an invasion of pathogens. Besides, it is known that in cells of leaves and shoots are occurs an increase in lignifications in responses to attack by pathogens (bacteria, fungi) [21]. Besides, it is known that epidermis is the one barrier and protection of leaf from action of ultraviolet, which is provoke both the intensified synthesis of lignin [22]. Taking into account the above and the results of our experiments the greatest fluorescence of monolignols the epidermis cell of leaves that situated under water surface, it is suggested that walls epidermis of studied leaves of hydrophytes protects of leaves from pathogens and even from little UV radiation in water.

Consider that with the increase of quantity of S/G as a chemical barrier increases to protecting of cells from penetration of water and invasion of pathogens [23]. Except it, it is known that this sign (S/G) testifies to the increase of mechanical durability of cells [24]. Taking into account, that the flooded leaves constantly are in a contact with a surrounding water micro flora and numerous alga, and also that flooded leaves undergo permanent pressure of water and action of waves [5] [25], it is possible to assume that periclinal and anticlinal walls of hydrophytes epidermis protect the surface of cells from exogenous influence of water surroundings therefore occurs defined synthesis of components of lignin. Notably, permanent water surroundings are one of basic exogenous factors of an increase synthesis of syringyl and guaiacyl in the leaves of the investigated hydrophytes. We see in addition, that a presence of these monolignols, and also their ratio in the cell walls of epidermis, parenchyma and vessels correlates with the data that were received of angiosperms dicotyledons upland plants [13] [26]. We do not eliminate, that the leaf cell walls of investigated hydrophytes contains and the third monolignol-p-hydroxyphenyl, that also plays a substantial role in lignin structure, and it is able determine with using other method, UV spectroscopy [27].

Thus, the obtained results revealed the particularities of syringyl and guaiacyl monolignols of cell walls of Myriophyllum spicatum. Potamogeton pectinatus and $P$. perfoliatus submerged leaves, which can be used as a basis for future study of both adaptation mechanisms of agricultural plants during flood, and possible for geneengineering of plant stability in flooded area.

\section{Conclusion}

Localization and relative content of syringyl and guaiacyl monolignols in Myriophyllum spicatum, Potamogeton pectinatus and $P$. perfoliatus submerged leaves were studied by the laser scanning microscopy. It was found that natural flooding caused the allocation of monolignols in cell walls dependence on leaf tissue and on species. The most content of monolignols was in walls of vessels, epidermis and in the interspaces (corners of cell junction) of photosynthetic parenchyma. We suggest that cell walls of leaf epidermis, as one main and first barrier between photosynthesizing parenchyma cells and water environment, protects of submerged plant from water pressure and from waves by the redistribution of syringyl and guaiacyl monolignols.

\section{References}

[1] Armstrong, W. and Drew, M.C. (2002) Root Growth and Metabolism under Oxygen Deficiency. In: Wasel, Y., et al., Plant Roots: The Hidden Yalf, 3rd Edition, New York and Basel, 729-761.

[2] Jackson, M.B. and Colmer, T.D. (2005) Response and Adaptation by Plants to Flooding Stress. Annals of Botany, 96, 501-505. http://dx.doi.org/10.1093/aob/mci205

[3] Parent, C., Capelli, N., Berger, A., Crevecoeur, M. and Dat, J. (2008) An Overview of Plant Responses to Soil Waterlogging. Plant Stress, 20, 20-27.

[4] Rose-John, S. and Kende, H. (1984) Effect of Submergence on the Cell Wall Composition of Deep-Water Rice Internodes. Plant Physiology, 76, 106-111. http://dx.doi.org/10.1104/pp.76.1.106 
[5] Nedukha, O.M. (2011) Heterophylly in Plants. Alt Press, Kiev, 1-191. (In Ukrainian)

[6] Little, S.T. (2003) Adaptation and Acclimaton of Populatons of Ludwigia Repens to Growth in High- and Lower-CO Springs. A Dissertation Presented to the Graduate School of the University of Florida in Partial Fulfillment of the Requirements for the Degree of Doctor of Philosophy. University of Florida, USA, 1-157.

[7] Nedukha, O. and Kordyum, E. (2013) The Participation of Cell Wall Polysaccharides in Cellular Mechanisms of Leaf Tolerance to Nature Flooding of Plant. In: Plant Functioning under Environmental Stress, 9th Intern Conf., Cracow, 12-15 September 2012, 137-152.

[8] Boerjan, W., Ralph, J. and Baucher, M. (2003) Lignin Biosynthesis. Annual Review of Plant Biology, 54, 519-546. http://dx.doi.org/10.1146/annurev.arplant.54.031902.134938

[9] Fengel, D. and Wegener, G. (1984) Wood Chemistry, Ultrastructure, Reaction. Walter de Gruyter, Berlin, 611.

[10] Monties, B. (1998) Novel Structures and Properties of Lignins in Relation to Their Natural and Induced Variability in Ecotypes, Mutants and Transgenic Plants. Polymer Degradation and Stability, 59, 53-64. http://dx.doi.org/10.1016/S0141-3910(97)00166-3

[11] Adler, E. (1977) Lignin Chemistry_Past, Present and Future. Wood Science and Technology, 11, 169-218.

[12] Leisola, M., Pastinen, O. and Axe, D. (2012) Lignin—Designed Randomness. Bio-Complexity, 3, 1-11.

[13] Weng, J.K., Takuya, A., Nichlolas, D., et al. (2010) Convergent Evolution of Syringyl Lignin Biosynthesis via Distinct Pathways in the Lycophyte Selaginella and Flowering Plants. The Plant Cell, 22, 1033-1045.

[14] Vartapetian, B., Andreeva, I., Maslova, I. and Davtian, N. (1970) The Oxygen and Ultrastructure of Root Cells. Agrochimica, 15, 1-19.

[15] Vartapetian, B. and Jackson, M. (1997) Plant Adaptation to Anaerobic Stress. Annals of Botany, 3, 3-20.

[16] Nekrasova, G., Ronzhina, D. and Korobizyna, E. (1998) Formation of the Photosynthetic Apparatus during Growth of Submerged, Floating and Above-Water Leaves in Hydrophytes. Russian Journal of Plant Physiology, 45, 539-548. (In Russian)

[17] Prokudin, J. (1987) Manual on High Plants of Ukraine. Naukova Dumka, Kiev.

[18] Dudar, T. and Zosimovich, A. (2011) Ecological Rating of Water Quality in Kiev Region. National Academy of Sciences of Ukraine, 2, 125-130.

[19] Wuyts, N., Lognay, G., Swennen, R. and De Waele, D. (2003) Secondary Metabolites in Roots and Implications for Nematode Resistance in Banana (Musa spp.) Proceedings of an International Symposium "Banana Root System: Towards a Better Understanding for Its Productive Management”, San José, 3-5 November 2003, 238-246.

[20] Carpita, N.C. and Gibeaut, D.M. (1993) Structural Models of Primary Cell Walls in Flowering Plants: Consistency of Molecular Structure with the Physical Properties of the Walls during Growth. The Plant, 3, 1-30.

[21] Moura, J.C., Bonine, C.A., Viana, J., Dornelas, M.C. and Mazzafera, P. (2010) Abiotic and Bitioc Stresses and Changes in the Lignin Content and Composition in Plants. Journal of Integrative Plant Biology, 52, 360-376. http://dx.doi.org/10.1111/j.1744-7909.2010.00892.x

[22] Hilal, M., Parrado, M., Rosa, M., Gallardo, M., Orce, L., Massa, M., Gonzabel, J. and Prado, F. (2004) Epidermal Lignin Deposition in Quinoa Cotyledons in Response to UV-B Radiation. Photochemistry and Photobiology, 79, $205-210$. http://dx.doi.org/10.1562/0031-8655(2004)079<0205:ELDIQC>2.0.CO;2

[23] Menden, B., Kohlhoff, M. and Moerschbacher, B.M. (2007) Wheat Cell Accumulate a Syringil-Rich Lignin during the Hypersensitive Resistance Response. Phytochemistry, 68, 513-529.

[24] Christiernin, M. (2006) Composition of Lignin in Outer Cell-Wall Layers. PhD Thesis, Division of Wood Chemistry and Pulp Technology, Royal Institute of Technology, Stockholm, 1-53.

[25] Tyree, M.T. and Cheung, Y.N.S. (1997) Resistance to Water Flow in Fagus grandifolia Leaves. Canadian Journal of Botany, 55, 2591-2599.

[26] Baucher, M., Monties, B., Van Montagu, M. and Boerjan, W. (1998) Biosynthesis and Genetic Engineering of Lignin. Critical Reviews in Plant Sciences, 17, 125-197. http://dx.doi.org/10.1016/S0735-2689(98)00360-8

[27] Koch, G. and Schmitt, U. (2013) Topochemical and Electron Microscopic Analyses on the Lignification of Individual Cell Wall Layers during Wood Formation and Secondary Changes. In: Fromm, J., Ed., Cellular Aspects of Wood Formation, Springer-Verlag, Berlin, 41-69. 